\title{
Identifikasi Arus Pasang Surut di Perairan Kemujan, Karimunjawa Berdasarkan Data Pengukuran Acoustic Doppler Current Profiler
}

\author{
Elis Indrayanti*, Denny Nugroho Sugianto, Purwanto, Hendry Syahputra Siagian
}

Departemen Oseanografi, Fakultas Perikanan dan Ilmu Kelautan, Universitas Diponegoro

Email: elisindrayanti@yahoo.com

\author{
Abstract \\ Identification of Tidal Current on Kemujan Waters, Karimunjawa Based on \\ Acoustic Doppler Current Profiler Data
}

\begin{abstract}
Ocean currents are dynamic hydro-oceanographic parameters which is play an important role in the transport of nutrients, larvae, sediment, and so on. Therefore, the identification of ocean currents including velocity, direction, sea level and the type of currents important to be studied. The research was conducted in Kemujan Water, Karimunjawa. Data for this research is based on velocity data measured using the Acoustic Doppler Current Profiler (ADCP) for $3 \times 24$ hours. Furthermore, the raw data of the measurement are analyzed using least square methods to obtain the characteristic of tidal current. The total current is separated into tidal currents and residual current (non-tidal currents). Result shown that the characteristic of current in Kemujan Water, Karimunjawa was tidal current. Tidal current moves bi-directional, toward the northeast and the southwest.
\end{abstract}

Keywords : tidal current, tides, Kemujan Island, ADCP

\begin{abstract}
Abstrak
Arus laut merupakan parameter hidro-oseanografi yang dinamis dan mempunyai peran penting dalam transpor nutrien, larva, material, dan lain sebagainya. Oleh karena itu identifikasi arus laut meliputi kecepatan, arah, elevasi muka air laut dan tipe arus laut perlu untuk dikaji. Penelitian dilaksanakan di Perairan Kemujan yang merupakan salah satu gugusan pulau di Karimunjawa. Data yang dianalisa merupakan data kecepatan arus hasil pengukuran langsung menggunakan Acoustic Doppler Current Profiler (ADCP) selama 3×24 jam. Selanjutnya raw data hasil pengukuran diolah dengan metode least square untuk mengetahui karakteristik arus. Arus total dipisahkan menjadi arus pasang surut dan arus non-pasang surut (residu). Hasil penelitian menunjukkan bahwa prosentase arus pasang surut lebih besar dari arus residu, sehingga arus di Perairan Kemujan, Karimunjawa teridentifikasi sebagai arus pasang surut. Arus bergerak secara bertolak belakang (bidirectional) yaitu pada saat surut menuju pasang arah arus menuju ke timur laut dan pada saat pasang menuju surut arah arus menuju ke barat daya.
\end{abstract}

Kata Kunci : pasang surut, arus pasang surut, Pulau Kemujan, ADCP

\section{PENDAHULUAN}

Arus laut sebagai dasar gerakan di samudra memegang peranan penting dalam transpor nutrien, transpor larva, transpor material, perkembangan perikanan laut, produktivitas primer permukaan, dan juga menunjang aktifitas manusia seperti dalam kegiatan pertambangan, pariwisata dan lain sebagainya (Zheng et al., 2018). Arus laut dapat dikategorikan berdasarkan gaya penggeraknya, salah satunya yaitu arus pasang surut. Arus pasang surut yaitu gerak horisontal badan air menuju dan menjauhi pantai seiring dengan perubahan naik turunnya muka laut. Perubahan naik turun 
muka laut disebabkan oleh gaya-gaya pembangkit pasang surut. Kecepatan arus pasang surut maksimum dan minimum dipengaruhi oleh perbedaan tinggi elevasi saat air tinggi atau air rendah (Purbandono \& Djunarsah, 2005; Mandang \& Yanagi, 2008; Siagian et al., 2019).

Pulau Kemujan merupakan salah satu dari 27 gugusan pulau-pulau di Kepulauan Karimunjawa, yang posisinya berada di Laut Jawa. Hidrodinamika pasang surut di Laut Jawa bersifat sangat kompleks, hal ini dikarenakan topografi dasar dangkal yang terjal, garis pantai yang rumit, dan terpengaruh gelombang pasang yang merambat dari Samudera Pasifik, Samudera Hindia, dan Laut Cina Selatan (Hasan \& Rambabu, 2017). Penelitian tentang arus di Karimunjawa sudah banyak dilakukan antara lain oleh Ismunarti et al. (2016) di Perairan Tanjung Batu Lawang, Karimunjawa, dan Indrayanti et al. (2020) di Perairan Pulau Cilik, Karimunjawa; dimana hasil penelitian menunjukkan bahwa perairan tersebut didominasi oleh arus pasang surut. Penelitian ini bertujuan untuk mengidentifikasi apakah tipe arus di Perairan Pulau Kemujan juga dominan dibangkitkan oleh pasang surut, berdasarkan data pengukuruan ADCP. Identifikasi dilakukan dengan memisahkan arus total menjadi arus pasang surut dan arus non-pasang surut/residu (Beliyana et al., 2020). Penggunaan data ADCP untuk analisa arus pasang surut sudah dilakukan pada penelitian-penelitian sebelumnya (Wang et al., 2004; Vindenes et al., 2018; Wisha et al., 2019; Siagian et al., 2021).

Karimunjawa merupakan kawasan perlindungan laut terbesar di Indonesia saat ini dan berperan penting dalam mendukung populasi lokal, termasuk perikanan lokal dan industri pariwisata yang terus berkembang (Hafsaridewi et al., 2018; Kennedy et al., 2020). Studi intensif tentang kondisi hidrodinamika perairan khususnya tipe arus laut dapat dijadikan dasar teori untuk penelitian lanjutan yang berkaitan dengan pola sirkulasi arus dan harapannya dapat menjadi salah satu informasi hidro-oseanografi dalam kegiatan monitoring dan pengembangan kawasan konservasi khususnya di Perairan Kemujan, Karimunjawa.

\section{MATERI DAN METODE}

Penelitian dilakukan pada bulan September - Oktober 2020 di perairan bagian barat Pulau Kemujan, Karimunjawa (Gambar 1). Data yang digunakan dalam penelitian adalah data hasil pengukuran ADCP dengan teknik mooring (tambatan di dasar laut) yaitu pada suatu titik tetap dan jangka waktu tertentu. Oleh karena itu titik lokasi pengukuran ditentukan dengan mempertimbangkan kondisi geometri perairan yaitu dasar yang datar.

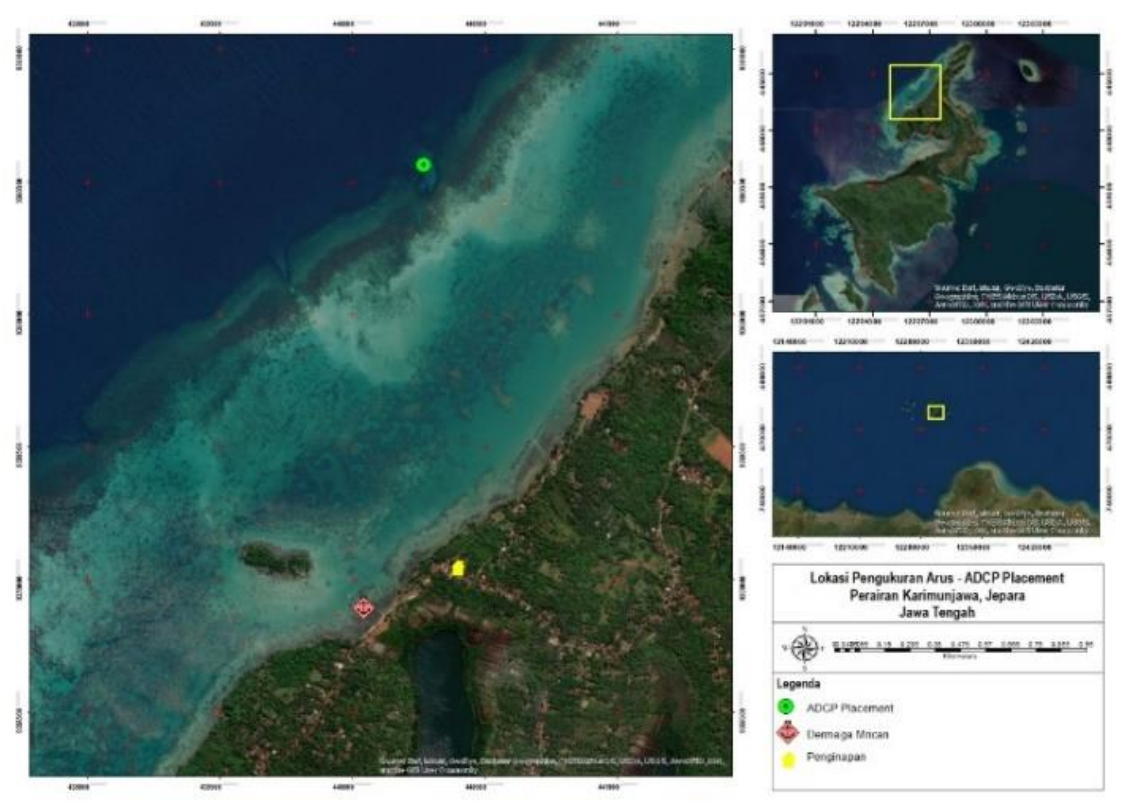

Gambar 1. Area penelitian Pulau Kemujan, Karimunjawa 
Kecepatan dan arah arus diukur dengan menggunakan ADCP tipe Multi Cell Argonaut- $X R$ dengan frekuensi $0,75 \mathrm{MHz}$ (Gambar 2). Akurasi yang dimiliki adalah 0.01 $\mathrm{cm} /$ det, dengan kedalaman kolom maksimal pengukuran $40 \mathrm{~m}$, maksimal lapisan (cell) yang dapat diukur adalah 10, dan tebal minimal lapisan adalah $0,8 \mathrm{~m}$ dengan kecepatan maksimal yang dapat terekam adalah $6 \mathrm{~m} / \mathrm{dt}$ (Sontek, 2006). Pengukuran dilakukan selama $3 \times 24$ jam (29 September sampai 2 Oktober 2020) dengan interval waktu rata-rata sebesar 300 detik, dan pelepasan gelombang akustik sampel adalah 15 detik. Pengukuran ini dilakukan bersamaan dengan pengukuran elevasi muka air, modul ADCP dilengkapi dengan pembaca perubahan tinggi elevasi air, dengan cara mengkonversi perubahan tekanan terhadap kedalaman pada persamaan hidrostatis. Hal ini juga bertujuan agar kedalaman aliran pada saat pengukuran kecepatan dapat diketahui, sehingga dapat dilakukan koreksi dalam proses berikutnya.

Kedalaman ukur adalah $12,6 \mathrm{~m}$ yang terbagi menjadi 8 lapisan dengan tujuan untuk mendapatkan profil kecepatan arus pada setiap lapisan secara vertikal. Sedangkan total kedalaman kurang lebih 14 $\mathrm{m}$, hal ini dilakukan dengan pertimbangan adanya perubahan tinggi muka air pada kolom air di dekat permukaan (Ren et al., 2015), tinggi dudukan frame ADCP, dan blank distance pada kolom air dekat dasar. Tebal tiap lapisan adalah 1,4 m. Titik kedalaman terakhir hingga permukaan merupakan daerah tunggang pasang surut, yang selanjutnya akan terukur pada layer dinamis, (extande range), ilustrasi ditampilkan pada Gambar 3.

Total data yang didapatkan dari hasil pengukuran adalah 1099 data selanjutnya dilakukan screening data yang ideal dapat digunakan adalah 1067 sampel. Data ini adalah sebesar $97,1 \%$ dari total data yang direkam, pengurangan ini terjadi karena beberapa faktor seperti pada saat pengukuran alat belum pada posisi duduk didalam air, dan pada saat selesai pengukuran perangkat belum dimatikan. Proses pengolahan data lainya adalah melakukan penyesuaian koreksi terhadap kondisi profil air. Beberapa penyesuaian adalah memasukan data eksisting suhu, salinitas, dan tekanan/kedalaman. Ketiga parameter ini mempengaruhi kualitas gelombang suara yang diterima perangkat. Suhu perairan pada saat pengukuran adalah $28^{\circ} \mathrm{C}$, Salinitas perairan adalah $33 \mathrm{ppt}$, dan koreksi kedalaman $14.4 \mathrm{~m}$.

Data kecepatan arus selanjutnya dianalisis dengan pendekatan metode least square (Shu, 2003; Foreman, 2004; Siagian et al., 2019), metode ini mengabaikan suku yang dipengaruhi oleh faktor meteorologi, dan persamaan yang digunakan adalah sebagai berikut:

$$
\begin{aligned}
h t_{i} & =S_{0}+\sum_{1}^{n} H_{n} \cos \left[\omega_{n} t_{1}+g_{n}\right] \\
h t_{i} & =S_{0}+\sum_{1}^{n} H_{n}\left[\cos \left(\omega_{n} t_{1}\right) \cos \left(g_{n}\right)\right. \\
h t_{i} & \left.=S_{0}+\sum_{1}^{n} A_{n} \sin \left(\omega_{n} t_{1}\right) \sin \left(g_{n}\right)\right] \\
& \left.-\sum_{1}^{n} B_{1}\right) \\
H_{n} & =\sqrt{A^{2}{ }_{n}+B^{2}{ }_{n}} \\
g_{n} & =\operatorname{arctg}\left(\frac{B_{n}}{A_{n}}\right)
\end{aligned}
$$

dimana, $A_{n}=H_{n} \cos \left(g_{n}\right)$ dan $B_{n}=H_{n} \sin \left(g_{n}\right)$ dalam meter; $h t_{i}$ merupakan elevasi dari komponen tunggang kecepatan arus (velocity-i); $H_{n}$ adalah amplitude dari komponen kecepatan; $\omega$ merupakan frekuensi yang diberikan masing - masing konstituen harmonic; $t_{1}$ adalah periode; $g_{n}$ phase pada komponen kecepatan dan $S_{0}$ tinggi muka air tetap pada meter.

\section{HASIL DAN PEMBAHASAN}

Hasil pengukuran arah, kecepatan dan elevasi muka air disajikan dalam Gambar 4, hasil yang ditampilkan merupakan fase pasang surut pada 
kondisi purnama (spring). Arah arus terlihat bertolak belakang (bi-derectional) dengan arah perpindahan adalah barat daya dan timur laut, range sudut $45^{\circ}-70^{\circ}$ dan sudut balik 1900-210。. Sementara untuk kecepatan arus maksimum terjadi pada saat-saat antara air tinggi dan air rendah yaitu pada saat surut menuju pasang sebesar $13.5 \mathrm{~cm} /$ det, dan pada saat pasang menuju surut juga terdapat beberapa kali kejadian arus maksimum dengan nilai $19.2 \mathrm{~cm} /$ det. Hal ini sejalan dengan Theoyana et al., (2015), yang menyatakan bahwa, nilai kecepatan arus dapat mencapai maksimum ketika muka air laut saat akan menuju pasang tertinggi
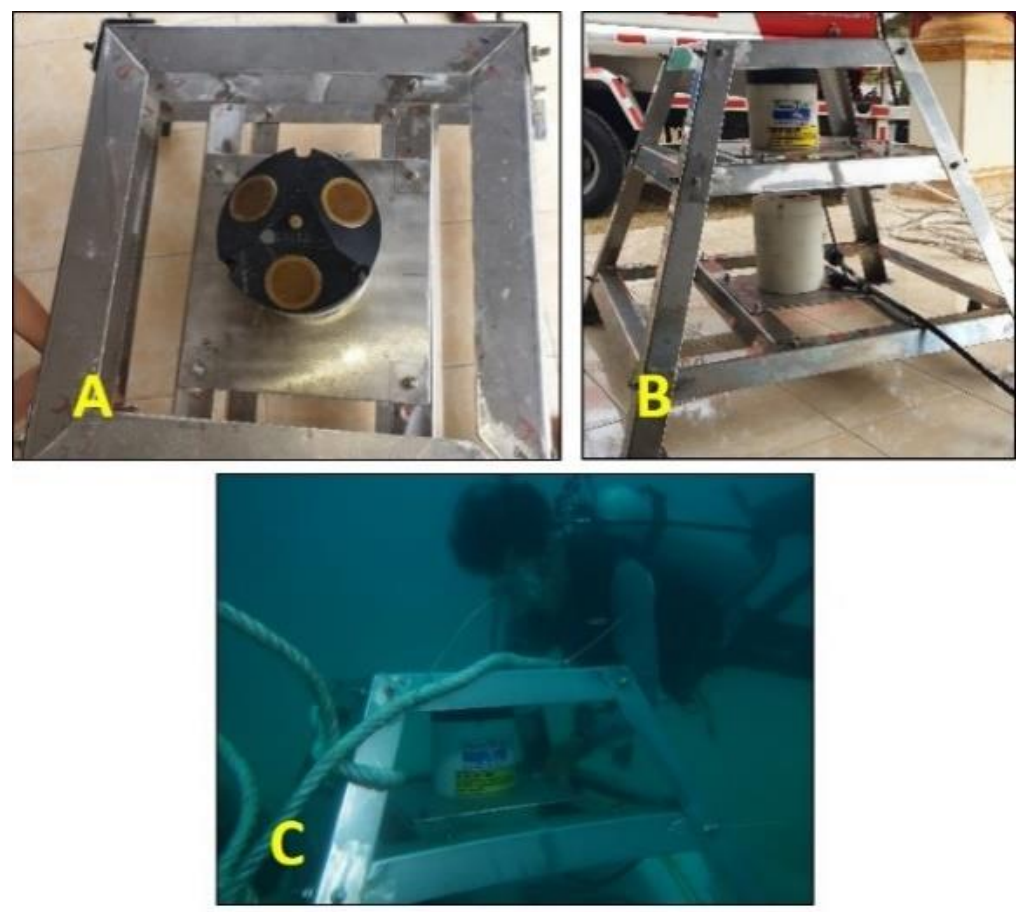

Gambar 2. ADCP ditempatkan pada frame (A \& B), ADCP pada kedalaman $14 \mathrm{~m}$ (C)

\begin{tabular}{l|l|l|}
\hline $2,8 \mathrm{~m}$ & Lapisan 1 \\
\hline $4,2 \mathrm{~m}$ & Lapisan 2 \\
\hline $5,6 \mathrm{~m}$ & Lapisan 3 \\
\hline $7,0 \mathrm{~m}$ & Lapisan 4 \\
\hline $8,4 \mathrm{~m}$ & Lapisan 5 \\
\hline $9,8 \mathrm{~m}$ & Lapisan 6 \\
\hline $11,2 \mathrm{~m}$ & Lapisan 7 \\
\hline $12,6 \mathrm{~m}$ & Lapisan 8 \\
\hline & Blank area $=0,7 \mathrm{~m}$ \\
\hline & Frame ADCP $=0,7 \mathrm{~m}$ \\
\hline
\end{tabular}

Gambar 3. Ilustrasi kolom lapisan ADCP di dalam air 
dan pada saat menuju surut terendah. Kedudukan bulan, bumi dan matahari (spring dan neap) juga berpengaruh terhadap perbedaan tinggi permukaan air laut yang akan mempengaruhi arah dan kecepatan arus yang terjadi. Penelitian sebelumnya oleh (Mandang \& Yanagi, 2008; Siagian, et al., 2019) menunjukkan bahwa kondisi elevasi pasang surut pada saat spring sangat mempengaruhi timbulnya arus maksimum, dibandingkan dengan kondisi pasut pada saat neap.

Kecepatan dan arah arus pada tiap lapisan kedalaman pengukuran tersaji pada Tabel 5, arus pada seluruh lapisan kedalaman memiliki kecepatan minimum antara 0.8-1.2 $\mathrm{cm} /$ det dan kecepatan maksimum berkisar antara 14.6-28.6 cm/det. Secara umum berdasarkan hasil pada tabel 1, kecepatan arus berkurang seiring dengan bertambahnya kedalaman, terlihat bahwa kecepatan arus maksimal berada pada kolom perairan yang paling dekat dengan permukaan. Pola profil kecepatan yang sama juga terjadi pada penelitian di Mandeh Bay, Sumatera Barat oleh Wisha et al. (2019), kecepatan arus di lapisan permukaan adalah yang terkuat dan secara bertahap menjadi lebih lemah dengan bertambahnya kedalaman. Hal ini diduga karena adanya pengaruh gaya coriolis dan efek gesekan dasar.

Hasil analisa komponen komponen arus timur - barat (u-velocity), maupun utaraselatan ( $v$-velocity) mempunyai pola yang sama). Kecepatan komponen arus timur barat sebesar $19 \mathrm{~cm} /$ det, dengan minimum maximum adalah -6.5-12.5 cm/det. Komponen utara - selatan sebesar $19.4 \mathrm{~cm} /$ det dengan nilai minimun $-8.7 \mathrm{~cm} /$ det dan maksimum 19.7 $\mathrm{cm} /$ det (Gambar 5).

Hasil pemisahan arus pasang surut (pengaruh astronomi) dan arus non-pasang surut (residu) tersaji pada Gambar 6 dan 7. Arus dominan Dibangkitkan oleh pasang surut dengan prosentase arus pasang surut

Tabel 1. Variasi kecepatan dan arah arus pada kolom vertikal air di Perairan Kemujan, Karimunjawa

\begin{tabular}{|c|c|c|c|c|c|c|}
\hline \multirow[t]{2}{*}{ Lapisan } & \multirow[t]{2}{*}{ Kedalaman } & \multicolumn{2}{|c|}{ Maksimum } & \multicolumn{2}{|c|}{ Minimun } & \multirow{2}{*}{$\begin{array}{c}\text { Kecepatan } \\
\text { Rata-Rata } \\
\text { (cm/det) }\end{array}$} \\
\hline & & $\begin{array}{c}\text { Kecepatan } \\
\text { (cm/det) }\end{array}$ & Arah (०) & $\begin{array}{c}\text { Kecepatan } \\
\text { (cm/det) }\end{array}$ & Arah (०) & \\
\hline 1 & $2,8 \mathrm{~m}$ & 28.6 & 108.7 & 1.2 & 12.3 & 5.60 \\
\hline 2 & $4,2 \mathrm{~m}$ & 27.8 & 326.5 & 1.1 & 341.6 & 5.81 \\
\hline 3 & $5,6 \mathrm{~m}$ & 26.5 & 332.1 & 0.9 & 128.7 & 5.64 \\
\hline 4 & $7 \mathrm{~m}$ & 19.1 & 335.7 & 0.9 & 315 & 5.60 \\
\hline 5 & $8,4 \mathrm{~m}$ & 17.7 & 309.6 & 1.2 & 140.2 & 5.29 \\
\hline 6 & $9,8 \mathrm{~m}$ & 17.6 & 68 & 1 & 211.2 & 5.25 \\
\hline 7 & $11,2 \mathrm{~m}$ & 15.2 & 52.1 & 1.2 & 39.8 & 5.29 \\
\hline 8 & $12,6 \mathrm{~m}$ & 14.6 & 152.5 & 0.8 & 129.1 & 4.80 \\
\hline
\end{tabular}

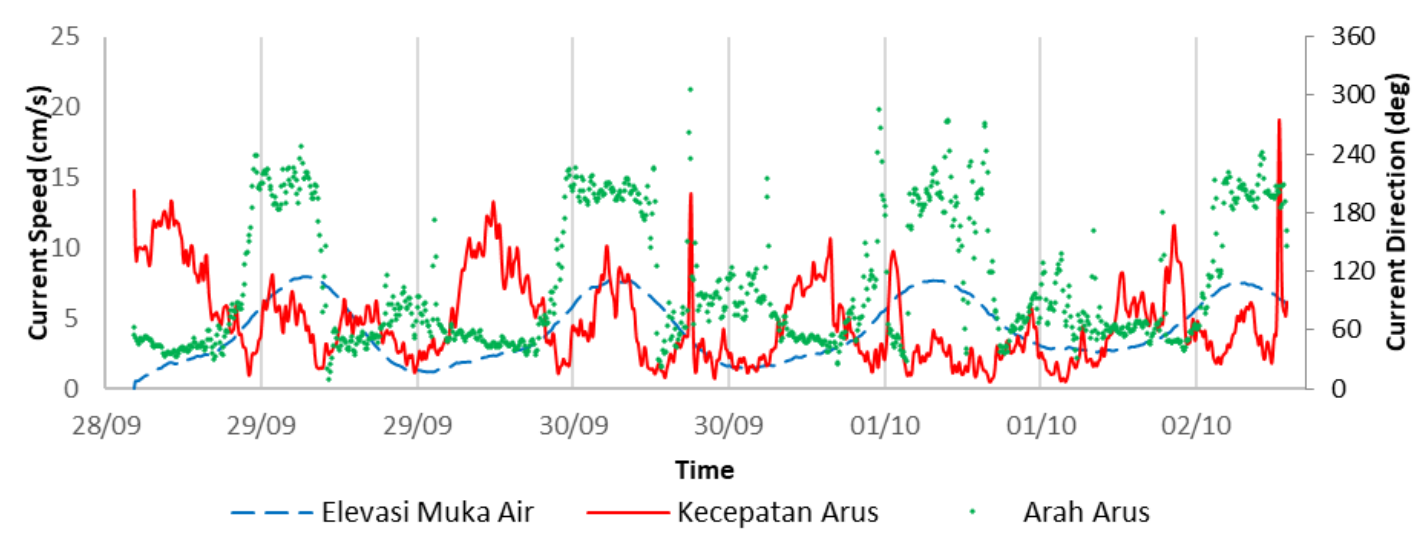

Gambar 4. Grafik hubungan antara elevasi muka air, kecepatan arus dan arah arus 
adalah $83,2 \%$ komponen arus utara-selatan (v-velocity) ditunjukan pada Gambar 6, sedangkan untuk komponen arus timur-barat (u-velocity) sebesar 80,67 \% (Gambar 7). Besar nilai dari komponen $v$ pada lokasi penelitian tidaklah lebih besar dibandingkan dengan besar nilai komponen $\mathrm{u}$, hal ini terjadi karena pergerakan arus di lokasi penelitian cenderung ke timur laut dan barat daya. Hal ini menunjukan komponen pembangkit astronomi memberikan kontribusi yang lebih dominan terhadap pergerakan masa air di perairan Pulau Kemujan, Karimunjawa.
Pengaruh pembangkit non-pasut atau residu memberi tambahan nilai vektor terhadap kehadiran arus. Hal ini mengakibatkan pergerakan arus pada arah - arah tertentu mendapatkan tambahan kecepatan terhadap vektornya, dan atau mengalami pengurangan kecepatan. Komponen utama arus residu di pantai adalah arus yang dibangkitkan oleh pasang surut non-linear, arus yang dibangkitkan oleh angin permukaan dan arus yang dibangkitkan oleh gradien densitas horizontal (Yanagi, 1999).

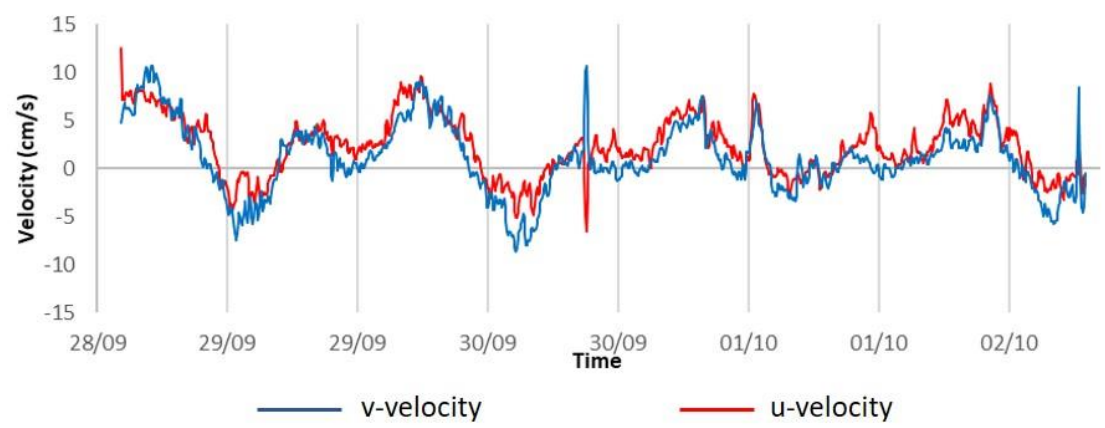

Gambar 5. Komponen kecepatan arus utara-selatan (v-velocity) dan komponen kecepatan timurbarat (u-velocity) Perairan Kemujan, Karimunjawa

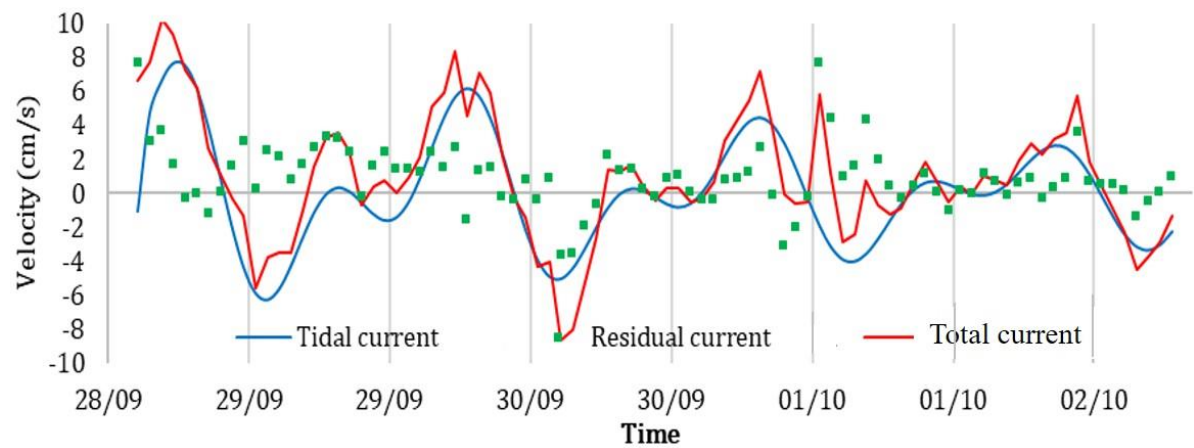

Gambar 6. Grafik arus pasang surut dan arus non pasang surut (residu) komponen utara - selatan di Pulau Kemujan, Karimunjawa

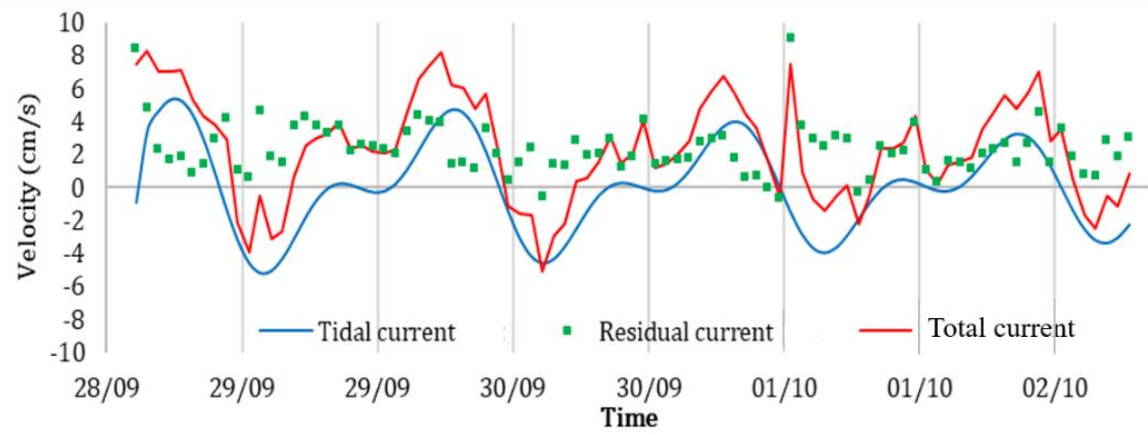

Gambar 7. Grafik arus pasang surut dan arus non pasang surut (residu) komponen barat - timur di Pulau Kemujan, Karimunjawa 


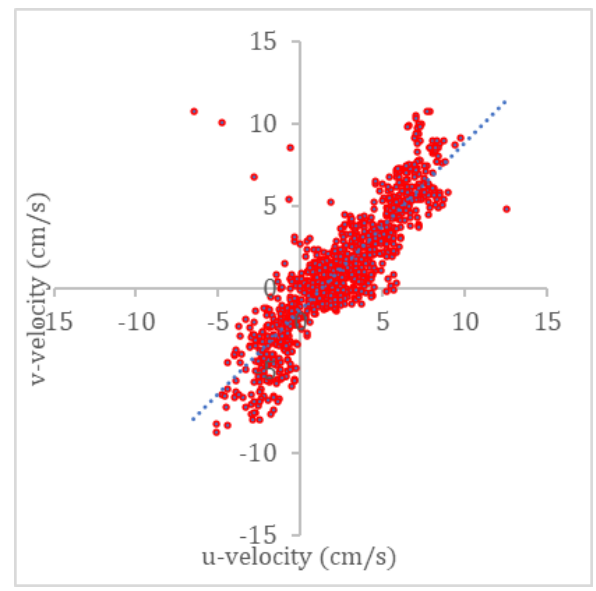

Gambar 8. Scatter plot untuk arah dan kecepatan arus rata-rata Perairan Kemujan, Karimunjawa

Pola yang terlihat pada gambar 8 membentuk ellips, hal ini menandakan bahwa arus di Perairan Kemujan, Karimunjawa di dominasi oleh arus pasang surut dan lengkungan ellips-nya menunjukkan arah dominasi dari sebaran data yaitu ke arah barat daya dan ke timur laut. Yanagi (1999) menyatakan bahwa salah satu tipe gerak arus pasang surut adalah gerak rotasi dimana di laut lepas, gerak rotasi berbentuk elips dengan arah rotasi searah dengan putaran jarum jam di belahan bumi utara dan berlawanan arah dengan jarum jam di belahan bumi selatan. Arus pasang surut yang teridentifikasi di Perairan Kemujan, Karimunjawa ini juga sesuai dengan hasil penelitian-penelitian sebelumnya yang menyatakan bahwa Perairan Karimunjawa arus lebih dominan dibangkitkan oleh pasang surut (BTNKJ, 2016; Ismunarti et al., 2016; Indrayanti et al., 2020). Karimunjawa berada di Laut Jawa sehingga kondisi hidrodinamikanya juga dipengaruhi oleh kondisi hidrodinamika Laut Jawa. Sementara itu hidrodinamika pasang surut di Laut Jawa sangat kompleks, yaitu dipengaruhi gelombang pasang yang merambat dari Samudera Pasifik, Samudera Hindia, dan Laut Cina Selatan (Mustaid \& Yanagi, 2013; Hasan \& Rambabu, 2017).

\section{KESIMPULAN}

Arus di Perairan Kemujan, Karimunjawa berdasarkan data pengukuran ADCP teridentifikasi sebagai arus pasang surut, dengan prosentase arus pasang surut lebih besar dari arus residu yaitu $83,2 \%$ untuk komponen arus utara-selatan ( $v$-velocity) dan untuk komponen arus timur-barat (u-velocity) sebesar 80,67 \%. Pergerakan arus bidirectional yaitu dominan ke timur laut dan ke barat daya. Kecepatan arus berkurang terhadap kedalaman, dimana arus maksimum terjadi pada saat surut menuju pasang dan pasang menuju surut.

\section{UCAPAN TERIMA KASIH}

Terima kasih kepada FPIK UNDIP dengan pendanaan hibah penelitian No. 014/UN7.5.10..2/PP/2020 tahun 2020. Penulis juga mengucapkan terima kasih kepada Balai Taman Nasional Karimunjawa atas ijin penelitian No. 1411/T.34/TU/SIMAKSI/09/2020. Terima kasih kepada reviewer yang telah menginvestasikan waktunya sehingga artikel ini menjadi lebih baik.

\section{DAFTAR PUSTAKA}

Beliyana, E., Radjawane, I.M., \& Susanto, R.D. 2020. Identification of Tidal Current Vertical Structure in Ombai Strait and Timor Passage. IOP Conf. Series: Earth and Environmental Science, 618:012010 doi: 10.1088/1755-1315/618/1/012010

BTNKJ (Balai Taman Nasional Karimunjawa). 2016. Statistik Balai Taman Nasional Karimunjawa Tahun $2016.133 \mathrm{hlm}$

Foreman, M.G.G. 2004. Manual for Tidal Currents Analysis and Prediction. Pacific Marine Science Report 78-6, Inst. of Ocean Sciences, Patricia Bay, Victoria, 
B.C. 70 pages. (Online revised version of 1978 original)

Hafsaridewi, R., Sulistiono, F.A., Sutrisno, D., \& Koeshendrajana, S. 2018. Resource management in the Karimunjawa Islands, Central Java of Indonesia, through DPSIR approach. Advances in Environmental Sciences, 10:7-22.

Hasan, S., \& Rambabu, C. 2017. Enhanced Representation of Java Sea Tidal Propagation through Sensitivity Analysis. Journal of Water Resource and Hydraulic Engineering, 6(1):9-21

Indrayanti, E., Wijayanti, DP., \& Siagian, H.R.S. 2020. Pasang Surut, Arus dan Gelombang Berdasarkan Data Pengukuran Acoustic Doppler Current Profiler di Perairan Pulau Cilik, Karimunjawa. Buletin Oseanografi Marina, 9(1): 37-44

Ismunarti, D.H., Sugianto, D.N., \& Ismanto, A. 2017. Kajian Karakteristik Arus Laut di Kepulauan Karimunjawa, Jepara, Prosiding Seminar Nasional Hasil-Hasil Penelitian Perikanan dan Kelautan ke-VI, Semarang

Kennedy, E.V; Vercelloni, J.; Neal, B.P; Ambariyanto; Bryant, D.E.P.; Ganase, A.; Gartrell, P.; Brown, K.; Kim, C.J.S.; Hudatwi, M.; Hadi, A.; Prabowo, A.; Prihatinningsih, P.; Haryanta, S.; Markey, K.; Green, S.; Dalton, P.; Lopez-Marcano, S.; RodriguezRamirez, A.; Gonzalez-Rivero, M.; \& Hoegh-Guldberg, O. 2020. Coral Reef Community Changes in Karimunjawa National Park, Indonesia: Assessing the Efficacy of Management in the Face of Local and Global Stressors. J. Mar. Sci. Eng., 8, 760. doi: 10.3390/jmse8100760

Mandang, I., \& Yanagi, T. 2008. Tide and Tidal Current in the Mahakam Estuary, East Kalimantan, Indonesia, Coastal Marine Science, 32(1):1-8.

Mustaid, Y., \& Yanagi, T. 2013. Numerical modeling of tidal dynamics in the Java Sea. Coastal Marine Science, 36(1):1-12

Poerbandono, D. E., \& Djunarsah, E. 2005. Survei Hidrografi. Refika Aditama Bandung. $61 \mathrm{hlm}$

Ren, L., Nash, S., \& Hartnett, M. 2015. Observation and Modeling of Tide- and Wind-induced Surface Currents in Galway Bay. Water Science and Engineering 8(4): 345-352
Sontek/YSI. 2006. SonTek/YSI Argonaut Acoustic Doppler Current Meter Technical Documentation. SonTek/YSI, San Diego.

Shu, J.J. 2003. Prediction And Analysis Of Tide And Tidal Currents. International Hydrographic Review, 4(2): 24 - 29

Siagian, H.R.S., Sugianto, D.N., \& Kunarso. 2019. Current Velocity Impacts from Interaction of Semidiurnal and Diurnal Tidal Constituents for Tidal Stream Energy in East Flores, IOP Conference Series: Earth and Environmental Science. doi: 10.1088/17551315/246/1/012056.

Siagian, H.R.S., Ismanto, A., Putra. T., \& Pranata, A. 2021. Stratification on the Vertical Structure of the Tidal Ellipse and Power Density Estimation in the Larantuka Strait, East Flores Based on ADCP Measurement Data. IOP Conference Series: Earth and Environmental Science. doi: 10.1088/17551315/750/1/012023.

Theoyana, T. A., W. S. Pranowo., Anastasia R.T.D.K., \& Purwanto. 2015. Karakteristik Arus Pasang Surut di Selat Badung, Bali. Jurnal Segara, 11 (2):115-123.

Zheng C., Xiao Z., Zhou W., Chen X., \& Chen X. 2018. Ocean Current Characteristics. In: 21st Century Maritime Silk Road: A Peaceful Way Forward. Springer Oceanography. Springer, Singapore. doi:10.1007/978-981-10-7977-1_4

Vindenes, H., Orvik, K. A., Soiland, H., \& Wehde, H. 2018. Analysis of tidal currents in the North Sea from shipboard acoustic Doppler current profiler data. Continental Shelf Research, 162:1-12. doi: 10.1016/j. csr.2018.04.001

Wang, Y.H., L.Y. Chiao, L.Y., Lwiza, K.M.M., \& Wang, D.P. 2004. Analysis of flow at the gate of Taiwan Strait. Journal of Geophysical Research, 109:C02025, doi: 10.1029/2003JC001937.

Wisha, U.J., Dhiauddin, R., \& Gemilang, W.A. 2019. Tidal Ellipses Analysis Based on Flow Model Hydrodynamic Data Acquisition in Mandeh Bay, West Sumatera. Journal of Geoscience, Engineering, Environment, and Technology, 4(2): 93-103

Yanagi, T. 1999. Coastal Oceanography. Ocean Science Research, Terra Sc Pbl, Tokyo. $162 \mathrm{p}$. 